\title{
WPŁYW UBÓSTWA (BIEDY) NA SOCJALIZACJĘ DZIECI I MŁODZIEŻY
}

\author{
Abstract \\ The impact of poverty (misery) on the socialisation of children and young people
}

Unemployment is one of the main factors causing problems in the functioning of the family and above all in the process of socialization. It is one of the causes of poverty and the process of marginalization of many families in Polish society. Poverty has a special impact not only on the functioning of the whole family but especially on the upbringing and behavior of children and youth, and promotes the development of dysfunction in the family. Poverty affects the sphere of personality, the ability to communicate in a peer environment, the spread of pathology among children and adolescents. This problem undoubtedly has a negative impact on shaping the worldview of young individuals who usually finish their education at the basic level. Unemployed families encounter many barriers on their way, which impede their lives and discourage them from functioning in society. Children, seeing the breakdown of their parents, are becoming negative about people and the world. Poverty is a phenomenon that mainly damages human life, although there are cases when it teaches people responsibility and social maturity.

Key words: unemployment, poverty, education, socialisation, autocreation, enculturation

Konsekwencją biedy jest deprywacja, która generuje okrucieństwo dzieci i okrucieństwo wobec dzieci.

(Radziewicz-Winnicki, Roter 2004: 184)

Wychowanie w rodzinie, gdzie brak jest środków finansowych na jej funkcjonowanie, ma ogromny wpływ na wszystkich jej członków, a przede wszystkim na dzieci, które dopiero kształtują swoją osobowość, swój światopogląd oraz perspektywy życiowe. Bieda warunkuje obniżenie aspiracji edukacyjnych dzieci i młodzieży, a co za tym idzie ich całą karierę zawodową. Rodziny, w których jest bezrobocie, napotykają wiele barier w swoim życiu codziennym, zniechęcają się też do funkcjonowania w społeczeństwie, a to prowadzi nawet do wykluczenia. Dzieci obserwując swoich rodziców, którzy są 
załamani faktem braku pracy i środków finansowych, często funkcjonują podobnie jak oni, nabierając negatywnego nastawienia do ludzi.

Ubóstwo można zdefiniować jako „stan poniżej pewnego zmiennego w czasie progu dochodowego lub progu realizacji potrzeb w odniesieniu zarówno do jednostki, jak i rodziny lub większej grupy społecznej" (Boczoń, Toczyński, Zielińska 1995: 341). Potocznie ubóstwo kojarzymy z biedą i brakiem środków finansowych do życia.

\section{Specyfika problemów rodziny bezrobotnej}

Rodziny, w których brakuje środków finansowych, natrafiają w swoim życiu codziennym na wiele problemów, wśród których można wyróżnić wysoki poziom ubóstwa, degradację społeczną, zakłócenia w życiu rodzinnym, powstawanie różnych patologii społecznych, jak również brak aspiracji edukacyjnych dzieci i młodzieży oraz negatywny wpływ na psychikę.

Bieda, jak podają Pilch i Lepalczyk (2003: 319), jest równoważnikiem ubóstwa i oznacza „brak dostatecznych środków materialnych do życia”. Wyróżnia się ubóstwo absolutne i względne. Ubóstwo absolutne oznacza stan niezaspokojenia minimalnych biologicznych potrzeb organizmu ludzkiego, natomiast ubóstwo względne obserwujemy:

jeśli w społeczeństwie występują duże nierówności, to najgorzej sytuowani jego członkowie, nawet gdy mają środki pozwalające zaspokoić więcej niż tylko podstawowe potrzeby, powinni być nazywani ubogimi [...]; przy ustaleniu ubóstwa trzeba brać pod uwagę przeciętny poziom życia będący udziałem innych członków społeczeństwa” (Pilch, Lepalczyk 2003: 320-321).

Wysoki poziom ubóstwa występuje w rodzinach osób bezrobotnych, gdzie brakuje środków pieniężnych na zaspokojenie podstawowych potrzeb członków rodziny. Najgorsza jest sytuacja w rodzinach, w których bez pracy jest obydwoje rodziców, a jedynym źródłem utrzymania staje się niewystarczający na wydatki zasiłek. W takich gospodarstwach domowych ogranicza się wydatki na żywność, co prowadzi do głodu oraz niedożywienia. W rodzinach, gdzie występuje długotrwałe bezrobocie, dochodzi do degradacji społecznej, która objawia się izolacją od reszty społeczeństwa i brakiem chęci utrzymywania kontaktu z osobami pracującymi. Często członkowie takich rodzin wpadają w konflikty społeczne i nierzadko z powodu bezrobocia są piętnowani przez resztę społeczeństwa, przez co staczają się na margines społeczny. Najczęściej zawierają znajomości tylko z osobami bezrobotnymi, tak samo utrzymującymi się z zasiłku, nierzadko popadają $\mathrm{w}$ alkoholizm, jak również stosują przemoc $\mathrm{w}$ rodzinie.

W rodzinach, w których występuje bezrobocie, pojawiają się różne zakłócenia w codziennym życiu rodzinnym, konflikty, wzajemne pretensje i bezradność wobec dzieci, gdyż bezrobotny rodzic przestaje być autorytetem dla dzieci. Zanika wówczas poczucie bezpieczeństwa, czyli ważna funkcja w życiu rodziny, która może powodować nawet rozpad takiej rodziny. Bieda może skłaniać członków rodziny do zachowań patologicznych, 
takich jak przemoc, prostytucja, rozboje, kradzieże, a nawet wymuszanie okupów. Cała ta sytuacja sprawia, że stopniowo zaczynają tworzyć zorganizowaną przestępczość. Bezrobotni rodzice nieraz sięgają po alkohol, żeby zapomnieć o problemach i życiu w biedzie. Dosyć często można spotkać rodziców, którzy jako długotrwale bezrobotni usilnie zmierzają do tego, żeby ich dzieci osiągnęły wyższe wykształcenie niż oni. Dzieci natomiast, nierzadko chcąc jak najszybciej odciążyć swoich rodziców w utrzymaniu oraz pomóc im materialnie, nie chcą się kształcić, brak im aspiracji edukacyjnych. Kończąc szkołę podstawową, rezygnują $\mathrm{z}$ dalszej nauki z powodu braku środków finansowych. Natomiast brak wykształcenia powoduje trudności w znalezieniu pracy, co prowadzi do bezrobocia i dziedziczenia biedy.

Brak pracy i środków do życia wpływa również na psychikę członków rodziny. Częstymi objawami są stany załamania u osób bezrobotnych, frustracja, stres, poczucie krzywdy, niesprawiedliwości czy zwątpienia. Wymienione stany psychiczne mogą mieć wpływ nie tylko na pogorszenie się stanu zdrowia, lecz także mogą powodować nasilanie się konfliktów społecznych. Postawy członków rodziny „oddziałują ujemnie na rodzinę, jej ogólne funkcjonowanie i niski stopień satysfakcji z rodzinnej egzystencji” (Kawula, Brągiel, Janke 2009: 299).

Negatywne skutki długotrwałego bezrobocia mają wpływ zarówno na kondycję materialną rodziny, jak i na sferę psychiczną, fizyczną i społeczną. W sferze materialnej widoczne jest ograniczenie wydatków na żywność, środki czystości, odzież, co powoduje tak zwaną prostą wegetację. U członków rodziny mogą się pojawiać depresje, stres, poczucie beznadziejności, nerwicowe zaburzenia emocjonalne, a nawet stany lękowe spowodowane obawą przed przyszłością. Wynikiem stresu i złego odżywiania mogą być problemy zdrowotne, a narastające konflikty wewnątrzrodzinne często prowadzą do trudności wychowawczych, a nawet do rozbicia rodziny.

Bezrobocie naraża rodzinę na liczne niedogodności, pozbawia możliwości zaspokojenia wielu ważnych potrzeb, zagraża prawidłowemu kształtowaniu się osobowości dzieci i powoduje utratę sensu życia i inne groźne skutki społeczne (Bocian 2005: 34).

Bezrobotni rodzice, którym brakuje środków finansowych do utrzymania rodziny, tracą poczucie bezpieczeństwa, uważają się za życiowych nieudaczników, boją się o przyszłość swojej rodziny, szczególnie dzieci. Brak pracy sprawia, że członkowie rodziny są odtrącani przez społeczeństwo, co powoduje poczucie osamotnienia, a nawet zniechęcenia do życia, co może prowadzić do depresji czy agresji. Długotrwałe pozostawanie bez pracy i nieradzenie sobie $z$ taką sytuacją mogą doprowadzić jednostkę do sięgania po różnego rodzaju używki, takie jak alkohol czy narkotyki, a osoby słabsze psychicznie mogą nawet podejmować próby samobójcze.

Bezrobocie ma również charakter moralny i moralne konsekwencje, godzi w godność osobową człowieka, gdyż jest niejako widzialnym, społecznie potwierdzonym znakiem jego małej wartości, niewystarczalności, zależności od anonimowych mechanizmów 
społeczno-gospodarczych, wyrazem jego społecznej degradacji (Nowak, Wysocka 2001: 221).

Długotrwałe bezrobocie osłabia aktywność zawodową i chęć powrotu bezrobotnego na rynek pracy. Motywacji do pracy u takich osób nie wyzwala ograniczony dostęp do różnych form rozwoju, przyjemności, uczestnictwa w organizacji czasu wolnego czy w kulturze. W domach rodzin osób bezrobotnych panuje napięta atmosfera, pogarszają się kontakty między członkami rodziny, co wpływa na jakość życia dzieci oraz zakłóca ich prawidłowy rozwój emocjonalny.

\section{Style wychowania dzieci w rodzinach z problemami ekonomicznymi}

Rodzina, zgodnie z Deklaracją Praw Człowieka, postrzegana jest jako podstawowa i naturalna komórka społeczna, która powinna zapewnić możliwość funkcjonowania wszystkim jej członkom. W literaturze przedmiotu znajdujemy stwierdzenie, iż:

[...] rodzina to podstawowa komórka społeczna organizująca konsumpcję. Aby to było wykonalne, niezbędne jest posiadanie mieszkania i jego wyposażenia: dach nad głową stanowi dla rodziny dobro podstawowe będące przedmiotem szczególnych starań zarówno w dążeniu do jego uzyskania, jak i utrzymania (Graniewska 2001: 14).

Natomiast Stanisław Kawula (1998: 283) stwierdził, że rodzina to: „,niemal dla każdego podstawowy czynnik stabilizacji, oparcia psychicznego o pomocy usługowo-materialnej oraz istotny czynnik wszelkiego wsparcia społecznego - w tym socjalnego".

W literaturze znajdziemy wiele definicji, które określają rodzinę jako instytucję, do której zaliczają się przede wszystkim rodzice i dzieci. Ojciec i matka, tworząc związek, mają decydujący wpływ na jego funkcjonowanie. Rodzice opiekują się swoimi dziećmi, uczą je nie tylko podstawowych form zachowania i życia w społeczeństwie, lecz także wyznaczają system wartości, zajmując się ich wychowaniem. To, w jaki sposób rodzice zajmują się swoimi dziećmi, jest zazwyczaj odwzorowane od ich rodziców. Zwykle nie mają oni żadnego przygotowania czy to praktycznego, czy to mentalnego, więc bardziej świadomie bądź nieświadomie odtwarzają metody wychowawcze stosowane w ich domach rodzinnych. Każda rodzina przyjmuje pewne założenia i style wychowania. „Styl wychowania charakterystyczny dla danej rodziny jest jakby odbiciem sposobów i metod oddziaływania na dziecko wszystkich członków rodziny" (Przetacznik-Gierowska, Włodarski 1998: 127). We współczesnych małych, dwupokoleniowych rodzinach o stylu wychowania decydują przede wszystkim rodzice, sprawujący jako jedyni funkcje wychowawcze. Dlatego ważne są ich poglądy na wychowanie, zdobyte doświadczenia oraz wyniesione z dzieciństwa obserwacje sposobów rozwiązywania problemów wychowawczych.

W pedagogice i psychologii wyróżnia się trzy podstawowe style wychowania, a mianowicie: styl autokratyczny, demokratyczny i liberalny. Zazwyczaj w praktyce żaden 
z nich nie występuje w czystej postaci, ale zwykle dominuje jeden z nich, który wpływa na całą atmosferę życia rodzinnego.

W stylu autokratycznym, opartym na przemocy, od dzieci wymaga się bezwzględnego posłuszeństwa i podporządkowania się wszystkim poleceniom oraz nakazom rodziców, a przede wszystkim ojca. Dzieci w tak funkcjonującej rodzinie mają ściśle określone prawa i obowiązki, doskonale wiedzą, co mogą, a czego im nie wolno. Kary i nagrody jako środki wychowawcze stosowane są konsekwentnie i bez możliwości negocjowania. Rodzice poprzez różne formy manipulacji bezwzględnie kontrolują zachowanie i postępowanie dzieci, nie dopuszczając dzieci do współdecydowania w sprawach rodzinnych. Wyróżnia się pewne odmiany stylu autokratycznego: „od surowego nadzoru, ostrych środków represji i stawiania wymagań przekraczających nieraz możliwości dziecka i wymagań dostosowanych do celu indywidualnego i rozwojowego" (Przetacznik-Gierowska, Włodarski 1998: 129). W pierwszej formie tego stylu wychowawczego, zakładającego pewien dystans wobec rodziców, występują kary i wzbudzanie lęku u dzieci. Rodzice pouczają i wydają rozkazy, gdyż komunikacja jest jednostronna. W drugiej formie rodzice okazują życzliwość wobec dzieci, chociaż połączona jest ona z przekonaniem polegającym na stałym kierowaniu dziećmi oraz ciągłym ich kontrolowaniu. Wynikający dystans między rodzicami a dziećmi nie wyklucza jednak serdeczności i wzajemnego okazywania uczuć. Taki styl wychowania może powodować negatywne skutki, gdyż może on wywoływać u dzieci zachowania despotyczne czy okrutne wobec innych, często słabszych kolegów. Dzieci z takich rodzin są zazwyczaj uległe i czują się zastraszone. Często nie potrafią samodzielnie myśleć i podejmować indywidualnych działań, może występować u nich agresja oraz opór w stosunku do nauki.

Styl demokratyczny to styl, w którym dzieci mają udział w życiu rodziny. Rodzice razem z dziećmi dyskutują, omawiają codzienne życie, współdziałają, planują wspólne spędzanie czasu wolnego. Oczywiście w takich rodzinach dzieci mają również ustalone prawa i obowiązki, które zostały wspólnie uzgodnione, a nie narzucone. Dosyć wcześnie u dzieci kształtuje się zdolność do samokontroli oraz samodyscypliny, opartej na zasadach i normach moralnych. Dzieci są silnie związane emocjonalnie z rodzicami, a uczucia między nimi są pozytywne, gdyż przeważają zaufanie i życzliwość.

Kolejny styl to liberalny, w którym występuje „niekonsekwentne wychowanie czy też ingerowanie w sprawy dziecka i w jego zachowanie wyłącznie od przypadku do przypadku" (Przetacznik-Gierowska, Włodarski 1998: 131). Dzieci zazwyczaj pozostawione są same sobie, rodzice nadmiernie nie kontrolują ich spraw, nawet tolerują ich aspołeczne zachowania, ogólnie brak jest kontroli i opieki rodziców. Rodzice świadomie i w sposób zamierzony chcą pozostawić całkowitą swobodę w przekonaniu, że nie wolno hamować aktywności dzieci i ich spontanicznego rozwoju. Najczęściej dzieci przyzwyczajone są do spełniania wszelkich swoich zachcianek przez rodziców przy jednoczesnym braku jakichkolwiek zakazów.

W rodzinach, gdzie występuje zjawisko bezrobocia, a co za tym idzie problem ze środkami finansowymi, zazwyczaj dominuje autokratyczny styl wychowania. Rodzice bywają surowi i agresywni względem dzieci, stosując zarówno przemoc fizyczną, jak i psychiczną. 
Problemy finansowe rodziny negatywnie wpływają na jej spójność, a trudności z zaspokajaniem podstawowych potrzeb mają swoje konsekwencje w jej funkcjonowaniu oraz wymuszonych zmianach. „Bieda może skłaniać rodzinę do zmiany tradycyjnego układu ról, sprawiając, że niezbędna staje się aktywność zawodowa (legalna albo "na czarno") matki przebywającej dotąd w domu" (Pietrzyk 2001: 32). W niektórych przypadkach to pracująca matka jest jedynym źródłem utrzymania rodziny. Wówczas wszyscy członkowie rodziny zmuszeni są do współdziałania, co prowadzi do zacieśniania więzów między nimi, jak również zwiększa wśród nich poczucie odpowiedzialności za całość rodziny.

Długotrwałe bezrobocie w rodzinie powoduje mimo wszelkich starań pogorszenie warunków życia, zwłaszcza warunków bytowych. Może to prowadzić do tak zwanego indywidualizmu rodzinnego albo nawet do amoralnego familizmu w skrajnych przypadkach. Takie zjawiska prowadzą do postępowania uczciwego i moralnego jedynie względem własnej rodziny, a rozwijają postawy egoistyczne, agresywne i wrogie wobec ludzi, a nawet instytucji. Powodują również brak dalekosiężnych celów oraz przywyknięcie do pomocy materialnej z zewnątrz. Dzieci pochodzące z ubogich rodzin często wykazują trudności z integracją ze środowiskiem rówieśniczym, gdyż czują się gorsze ze względu na swój ubiór, niedożywienie, brak modnych i firmowych zabawek czy przyborów szkolnych. Zazwyczaj są nieśmiałe i wycofane bądź odwrotnie - agresywne i zaczepne, sprawiające trudności wychowawcze. Ze względu na biedę dzieci bardzo często spędzają wolny czas w domu, a niejednokrotnie starają się zdobywać środki na utrzymanie rodziny. Brak pieniędzy powoduje ograniczenia w edukacji, kulturze oraz nieutrzymywanie kontaktów towarzyskich wszystkich członków rodziny, skazanych na swoje towarzystwo, niezależnie od tego, jakie panują między nimi stosunki.

Postawa autokratyczna rodzica może doprowadzić do aspołecznych postaw u dzieci. Jedne będą despotyczne i nieustępliwe, okrutne wobec słabszych, drugie będą zbuntowane. Jeszcze inne mogą być uległe, zastraszone, charakteryzujące się brakiem samodzielności, a nawet zwiększeniem infantylizmu.

W rodzinach, w których występuje zjawisko ubóstwa, można także zaobserwować styl liberalny, gdyż z powodu braku środków finansowych rodzice odczuwają bezradność, załamanie, a nawet depresję. Wówczas dzieci pozostawione są bez opieki, mają pełną swobodę, mogą robić, na co mają ochotę. Z powodu braku kontroli rodzicielskiej dzieci mogą wracać do domu w godzinach nocnych, częstokroć wpadają w nieodpowiednie towarzystwo i komunikują się tylko z tymi osobami, które mają podobne problemy.

Dzieci pochodzące z rodzin, gdzie występuje bezrobocie, często wykazują trudności w nawiązywaniu kontaktów, a więc trudno im się odnaleźć w grupach rówieśniczych. Ze względu na doświadczaną biedę dzieci często szukają towarzystwa starszych od siebie, by dzięki nim znaleźć jakieś źródła dochodu i pomóc w utrzymaniu rodziny. Tym bardziej że nie są one obciążone obowiązkami domowymi, a większość czasu spędzają poza domem. Zdarza się, że dzieci chcą być lepsze niż rodzice, chociaż z różnym skutkiem. Rodzice nie są dla nich autorytetem, a wręcz przeciwnie. Świat marzeń tych dzieci jest minimalistyczny, koncentruje się na modelu odmiennym od tego, co na co dzień doświadczają w swym domu. 
Duża swoboda w stylu wychowania w rodzinach liberalnych może mieć negatywne skutki, gdyż w celu osiągania własnych potrzeb może prowadzić dzieci do kradzieży, uczestnictwa w grupach przestępczych, włóczęgostwa, nielegalnej pracy, bójek, a nawet wyłudzania pieniędzy od młodszych i słabszych. Dzieci wychowywane w takich rodzinach często przejawiają zachowania antyspołeczne, impulsywne czy agresywne. Niekoniecznie widzą je u swoich rodziców, lecz u osób z różnych grup społecznych, w których przebywają na ulicy.

\section{Wychowanie, socjalizacja, autokreacja i enkulturacja w środowisku rodziny bezrobotnej}

W środowisku rodzin bezrobotnych istnieje specyficzne podejście do wychowania, socjalizacji, autokreacji czy enkulturacji. Ze względu na marginalizację społeczną członkowie tych rodzin pomału tracą zaufanie do otaczającego ich świata i dochodzą do przekonania, że ludzie stanowią dla nich zagrożenie. Źródłem takiego zagrożenia może być również sytuacja domowa, napawająca ich lękiem i prowadząca nawet do depresji. Ukształtowana w wyniku doświadczeń z wczesnego dzieciństwa skłonność do spostrzegania świata jako źródła zagrożenia może mieć tendencję do generalizowania i utrwalania się. Dzieci wychowywane w takich rodzinach w dużym stopniu narażone są na powielanie takich niebezpiecznych wzorców rodzinnych.

Wychowanie to przede wszystkim „kształtowanie człowieka we wszystkich dziedzinach jego życia i aktywności” (Dawid 2002: 9). Takie oddziaływanie na jednostkę jest istotne zwłaszcza w przypadku dzieci. Już od wczesnego dzieciństwa jednostka powinna mieć przekazywane wartości moralne, etyczne oraz odpowiednio kształtowaną postawę. Prawidłowo wychowane dzieci powinny przejawiać postawy, które przede wszystkim „polegają na zdobywaniu wiedzy o otaczającej nas rzeczywistości po to, aby móc w niej działać rozumnie i świadomie” (Misiewicz 1986: 115).

Władysław Łobocki stwierdził, że „wychowanie następuje zarówno w środowisku naturalnym, jak i intencjonalnym" (Łobocki 2003: 45). Do tego środowiska naturalnego zalicza rodzinę i środowisko rówieśnicze, a do intencjonalnego przede wszystkim szkołę, internat czy dom dziecka. Prawidłowo funkcjonująca rodzina powinna spełniać kilka bardzo ważnych funkcji w procesie wychowania, a mianowicie: socjalizującą, usługowo-opiekuńczą, psychologiczną, zarobkową oraz prokreacyjną. To w środowisku domowym dziecko uczy się określonych zachowań, które są demonstrowane przez osoby najbliższe, czyli przez rodziców. Dzieci poprzez obserwację nieświadomie przejmują wartości matki i ojca. Jeśli rodzice są osobami bezradnymi, pokrzywdzonymi, nieszczęśliwymi, bezrobotnymi, o postawie roszczeniowej, to prawdopodobnie dzieci też przyjmą takie same postawy i zachowania.

Każda jednostka, zwłaszcza młoda, ma potrzebę przynależności do jakiejś grupy społecznej, w której będzie akceptowana. Dzieci chętnie przebywają wśród kolegów i koleżanek o podobnych zainteresowaniach. Bywa też, że dzieci skonfliktowane z rodzicami 
szukają wsparcia wśród rówieśników i przyłączają się do grup zdemoralizowanych, będących w konflikcie z prawem bądź preferujących styl życia „dzieci ulicy”. Dlatego tak ważne jest, by z powodu bezrobocia rodziców dzieci nie izolowały się od grupy rówieśniczej prawidłowo funkcjonującej, by system wsparcia społecznego przeciwdziałał stygmatyzacji tych dzieci przez ich świat rówieśniczy. Współcześnie, jak zauważa Zygmunt Bauman (2006: 25), bycie wykluczonym oznacza również bycie zbędnym, niepotrzebnym, bezużytecznym.

Pobyt dzieci w szkole czy w internacie jest znaczący dla ich rozwoju i sposobu zaspokajania potrzeb, gdyż w ciągu dnia spędzają tam większość swojego czasu. Dlatego zwraca się uwagę na wpływy wychowawcze, które oddziałują na młodego człowieka. Dom dziecka jako placówka opiekuńczo-wychowawcza ma za zadanie zastąpić dziecku rodziców i przygotować je do samodzielnego życia.

Rodzinom, w których występuje bezrobocie, trudno jest wychować dzieci i przekazać odpowiednie wartości, gdyż brak środków finansowych nie kształtuje właściwych warunków socjalno-bytowych. „Bieda ma niszczący wpływ na rozwój dziecka oraz jego późniejsze wyniki w nauce, szanse na pracę, oddziaływanie na zdrowie oraz zachowanie" (Lister 2007: 89).

Wychowawcze oddziaływanie rodziny ma istotny wpływ na socjalizację dzieci i młodzieży na drodze nieświadomego przekazywania wiedzy o otaczającym świecie wraz $\mathrm{z}$ wartościowaniem go i preferowaniem wzorów zachowań. Socjalizacja jest „procesem nabywania umiejętności pełnienia ról społecznych i odbywa się ona w warunkach kontroli społecznej, która polega na spontanicznym reagowaniu otoczenia na różne zachowanie się jednostki" (Górski 1985: 7). Wyróżnia się dwa rodzaje socjalizacji, a mianowicie socjalizację pierwotną i wtórną. Socjalizacja pierwotna odbywa się w domu rodzinnym i jest procesem uspołeczniania się dziecka głównie przez identyfikację z osobami dla niego znaczącymi. Jest również procesem przyjmowania/uwewnętrzniania preferowanych przez starszych członków rodziny wartości. Natomiast socjalizacja wtórna odnosi się przede wszystkim do okresu podziecięcego, czyli tego, w którym młody człowiek nabywa umiejętności i kompetencje społeczne poza domem. Od dawna badacze wskazują, że na socjalizację młodego człowieka duży wpływ ma również środowisko zewnętrzne. „Każde środowisko ludzkie bezustannie przekształca się pod wpływem działalności społecznej" (Pieter 1972: 119). Oba rodzaje socjalizacji są bardzo ważne w całym procesie kształtowania osobowości i tożsamości jednostki, gdyż mają na nią ogromny wpływ. Dlatego też rodzice powinni prezentować normy i wartości zgodne z oczekiwaniami społecznymi oraz kontrolować środowisko, w którym ich dziecko funkcjonuje, aby nie przyczyniło się do degradacji jego osobowości.

Bieda i rodzaj naznaczenia nie są podstawą procesu marginalizacji i wykluczenia. $U$ dzieci niedostatek materialny utrudnia budowanie własnego kapitału edukacyjnego, zmniejsza możliwości nawiązywania i utrzymywania relacji rówieśniczych istotnych w procesie socjalizacji. Bezrobocie, w szczególności długotrwałe, przesuwa dorosłych i ich dzieci na margines społeczeństwa, ponieważ 
praca we współczesnym świecie jest „biletem wstępu do świata zasobów” (Płusa 2015: 37; Miś, Nóżka, Smagacz-Poziemska 2011).

Pojęciem bliskim socjalizacji jest enkulturacja polegająca przede wszystkim na świadomym i nieświadomym nabywaniu kompetencji kulturowych, przekazywanych z pokolenia na pokolenie, które tworzą system wartości danej grupy. Enkulturacja to proces wrastania w kulturę danego społeczeństwa. Proces ten sprawia, że jednostka staje się integralnym członkiem i nosicielem jego kultury. $\mathrm{W}$ uświadomionym procesie enkulturacji chodzi o intencjonalne przekazywanie systemu wartości przez różne instytucje kulturalne, a w procesie nieuświadomionym następuje przekazywanie trafnego wartościowania rzeczywistości zgodnie z przyjętymi w kulturze formami jej kategoryzowania i osądzania. Każde pokolenie przejmuje system wartości charakterystyczny dla danej kultury. Enkulturacja gwarantuje ciągłość ponadpokoleniową, jak również pomaga nowym pokoleniom $\mathrm{w}$ przystosowaniu się do zmian zachodzących w społeczeństwie.

Tworzenie własnego wizerunku przez daną osobę to autokreacja. Jednostki bezrobotne kreują się przeważnie jako osoby bezradne, pokrzywdzone i nieszczęśliwe. Częstokroć okazuje się, że ten wizerunek jest złudny, gdyż bezrobotni wielokrotnie twierdzą, iż taka sytuacja jest dla nich korzystna i nawet komfortowa. Żyjąc z przysługujących im zasiłków, wysyłając dzieci do różnych placówek opiekuńczo-wychowawczych, przyczyniają się do tworzenia ich wizerunku. $\mathrm{Na}$ ten wizerunek oddziałuje również środowisko, w którym się dzieci wychowuje i w którym odnajdują one swoją przestrzeń odniesienia, na przykład przynależność do grupy przestępczej. Bywa, że dzieci z rodzin bezrobotnych przyjmują wizerunek niezgodny z ich osobowością, ale wytworzony na pokaz. Zjawisko to wiąże się z przedstawianiem siebie wśród znajomych z jak najlepszej strony i nosi nazwę autoprezentacji pozytywnej. Zdarza się także odwrotnie, prezentowanie swojej osoby ze złej strony - autoprezentacja negatywna. Ogólnie autoprezentacja jest „celowym działaniem, ukierunkowanym na wywołanie pożądanego przez daną jednostkę wizerunku własnej osoby u osób z otoczenia społecznego" (Konopczyński 2006: 109). $\mathrm{U}$ dzieci pochodzących $\mathrm{z}$ rodzin biednych możemy spotkać się z „manipulacją innymi ludźmi”, w czym pomaga odpowiednia autoprezentacja. Dzięki wiedzy przekazanej przez rodziców dzieci mają pełną świadomość, że ich trudna sytuacja materialna może wywrzeć pożąany skutek społeczny.

Społeczeństwo odpowiedzialne jest za kształtowanie jednostki, która dopiero uczy się życia oraz reguł w nim obowiązujących. W młodzieńczym wieku kształtuje się także światopogląd człowieka, dlatego tak ważny jest rodzaj wpływu różnych środowisk oddziałujących na jednostkę. Młody człowiek próbuje złożyć w całość zdobyte fragmenty wiedzy społecznej i odnaleźć swój własny indywidualny stosunek do świata wartości. Nie zawsze jednak ten obraz ma pozytywne zabarwienie. Tym bardziej bezrobotni rodzice, wychowując swoje dzieci, powinni zadbać o odpowiednie oddziaływania, odpowiednią enkulturację, gdyż „dzieci wchodzą do kultury przez swoje rodzinne pochodzenie” (Kwak, Mościskier 2002: 27). To właśnie rodzice powinni nauczyć dzieci form grzecznościowych oraz zasad przyzwoitego zachowania, ale w rodzinach borykających się z brakiem 
środków finansowych często występuje taki deficyt, ponieważ sami rodzice takich reguł nie znają ani nie przestrzegają. Bywa również, że rodziny bezrobotne zasiedlają mieszkania o podobnym profilu mieszkańca - enklawy biedy (Warzywoda-Kruszyńska 2010), więc wszyscy mieszkańcy są na podobnym poziomie rozwoju osobistego, ekonomicznego i socjalnego. Takie siedliska ubóstwa i biedy nie służą rozwojowi dobrego wychowania, wręcz przeciwnie. Osoby wychowujące się w zdegradowanym środowisku odtwarzają zachowania przejawiane przez rodziców, zwłaszcza w sytuacjach, gdy są bezradne, na przykład zaczynają krzyczeć, używać wulgaryzmów, a nawet stają się agresywne.

\section{Rodzinne uwarunkowanie startu społecznego i edukacyjnego dzieci i młodzieży}

Rodzina jako najmniejsza grupa społeczna ma na celu wychowanie młodego pokolenia i przygotowanie go do życia w społeczeństwie. Rodzina przekazuje wartości, normy i daje początek poglądom na otaczający świat, ludzi i instytucje społeczne. We wczesnym dzieciństwie młody człowiek stara się postępować identycznie jak jego rodzice, ucząc się podobnego zachowania $\mathrm{w}$ różnych sytuacjach oraz przejmując poglądy na różne sprawy. Tak jak rodzice postrzegają rzeczywistość, tak ich dziecko będzie ją widziało.

Start społeczny dzieci jest uwarunkowany przez rodzinę, a nastawienie rodziców do społeczeństwa dziedziczone przez dzieci, które prezentują je w późniejszym życiu. Dzieci pochodzące z rodzin bezrobotnych są piętnowane przez społeczeństwo jako klasa niższa, która nie zasługuje na szacunek, gdyż nie pracuje i żyje z państwowych funduszy. Rodziny bezrobotne regularnie korzystają ze świadczeń socjalnych oraz instytucji państwowych, które oferują im pomoc. Młody człowiek pochodzący z rodziny bezrobotnej, ze względu na swoją sytuację materialną i pochodzenie, często ma problemy w nawiązywaniu kontaktów z rówieśnikami. Prowadzi to do alienacji, izolacji, wykluczenia i marginalizacji, a nawet do przyjęcia roli outsidera. Sam fakt urodzenia się w rodzinie bezrobotnej w obecnych warunkach społecznych determinuje obecne i przyszłe życie młodego człowieka. „Bieda dzieci jest wynikiem trudnej sytuacji materialnej rodziny, co wiąże się z nieprawidłowym funkcjonowaniem $\mathrm{w}$ sferze zaspokajania potrzeb nie tylko materialnych, ale także emocjonalnych i relacyjnych" (Płusa 2015: 39).

Rodzice ze względu na niski poziom materialny i finansowy spowodowany brakiem wystarczających dochodów nie mogą zaspokoić oczekiwań konsumpcyjnych swoich dzieci. Dzisiejszy rynek oferuje ogrom atrakcyjnych towarów, a mass media lansują określony poziom życia, niedostępny dla ubogich. To przyczynia się do obniżania pozycji dzieci z rodzin bezrobotnych w środowisku rówieśniczym.

Dziecięcej biedy nie można utożsamiać wyłącznie ze statusem materialnym rodziny. To także brak więzi emocjonalnych, miłości, brak możliwości prawidłowego rozwoju, $\mathrm{w}$ tym intelektualnego. W związku z tym zwalczania biedy nie można ograniczyć jedynie do zwiększenia jej zasobów materialnych, choć one niewątpliwie są pierwotną przyczyną ubóstwa w rodzinie. W przezwyciężaniu biedy dzieci należy zwrócić szczególną 
uwagę na usługi społeczne, a w szczególności edukację, która może pomóc w przerwaniu międzypokoleniowej transmisji biedy, a także na rozwiązania w zakresie polityki mieszkaniowej, zdrowotnej oraz opieki społecznej (Płusa 2015: 40).

Wpływ rodziny bezrobotnej widoczny jest również w zakresie nauki i wykształcenia dzieci. Młodzi ludzie pochodzący z rodzin bezrobotnych wykazują duże trudności i braki w nauce. Brak zainteresowania oraz pomocy ze strony rodziców sprawia, że start edukacyjny jest na niskim poziomie, a rozwój dydaktyczny jest znikomy. Często zdarza się, że w szkole odnotowuje się u tych dzieci drugoroczność będącą następstwem nieopanowania obowiązującego materiału albo wagarowania. Zazwyczaj dzieci pochodzące $\mathrm{z}$ rodzin bezrobotnych podobnie jak rodzice mają małe aspiracje w zakresie swojego wykształcenia i przyszłego zawodu. Bezrobotni rodzice popierają dążenie dzieci do szybkiej niezależności materialnej oraz usamodzielnienia poprzez zdobycie pracy. W opinii tych rodziców wykształcenie stanowi mało ważny aspekt życia, a praca nie jest wartością, do której należy dążyć. Rodzice nieposiadający pracy wykazują negatywny stosunek do edukacji, nieświadomie przekazując to swoim dzieciom. Ponadto bezrobotni rodzice nie wierzą w możliwości edukacyjne swoich dzieci, co przekłada się bezpośrednio na ich poczucie wartości i samoocenę.

Niepowodzenie w osiągnięciu zamierzonego celu czy też w realizacji własnego planu może stać się przyczyną niezadowolenia, frustracji, poczucia niskiej wartości oraz może prowadzić do stanu bierności i apatii. Powtarzanie się niepowodzeń w tej samej dziedzinie działań najczęściej wywołuje trwałe efekty, które M. Seligman nazwał wyuczoną bezradnością (Ratajczak 2001: 22).

Rodzice powinni być dla dzieci wsparciem i motywować do nauki oraz osiągania sukcesów, rozwijania swoich umiejętności i zainteresowań.

Zdarzają się jednak przypadki, kiedy dzieci chcą osiągnąć w życiu więcej niż bezrobotni rodzice i chętnie się uczą, planując swoją karierę zawodową. Niestety, nierzadko pojawia się bariera wynikająca $\mathrm{z}$ trudności finansowych, co utrudnia im zdobywanie wykształcenia.

Reasumując, rodzina niewątpliwie warunkuje start społeczny oraz edukacyjny dzieci, a te wywodzące się z rodzin bezrobotnych zapewne mają utrudnione życie. Bieda i ubóstwo wpływają na socjalizację dzieci i młodzieży, gdyż z powodu braku wielu rzeczy, którymi dysponują rówieśnicy, są automatycznie wykluczeni. Bezrobocie rodziców rzutuje na nawiązywanie kontaktów w szkole. W oczach rówieśników ubodzy koledzy czy koleżanki uchodzą za osoby gorsze, niegodne szacunku, a nawet bywają ośmieszane $z$ tego powodu, przez co przyjmują postawę obronną i wycofującą. Tracą zaufanie do ludzi, środowiska oraz utwierdzają się w przekonaniu, że są inni, nierzadko gorsi.

Bieda niewątpliwie wpływa na kształtowanie się osobowości dzieci i młodzieży, ich obrazu świata oraz dojrzałości społecznej. Dzieci z rodzin bezrobotnych przejawiają takie cechy, jak: wstyd, małomówność, nieśmiałość, zamknięcie się w sobie, a czasem bezczelność oraz roszczeniowość. Postrzegają świat jako niesprawiedliwy, okrutny i beznadziejny. Zazwyczaj prezentują zachowania nacechowane negatywnie, a wszelkie 
problemy związane $\mathrm{z}$ biedą stanowią przeszkodę w nawiązywaniu poprawnych relacji $\mathrm{z}$ rówieśnikami i światem dorosłych.

Ubóstwo i bieda mają znaczący wpływ na szerzenie się patologii społecznej wśród dzieci i młodzieży. Wykazują oni częściej niż ich rówieśnicy objawy demoralizacji i wkraczają na drogę przestępczą, dopuszczając się czynów zagrożonych karą. Przyczyn takiego zachowania należy upatrywać zarówno w normach i wartościach przekazywanych przez rodziców, problemach finansowych w rodzinie, jak i w braku zainteresowania ze strony najbliższych oraz chęci zarobienia pieniędzy.

\section{Bibliografia}

Bauman Z. (2006). Życie na przemiał. Wydawnictwo Literackie, Kraków.

Bocian F. (2005). Sytuacja opiekuńczo-wychowawcza $w$ rodzinach $z$ problemem bezrobocia. „Bytomskie Zeszyty Pedagogiczne”, 9.

Boczoń J., Toczyński W., Zielińska A. (1995). Ubóstwo jako zjawisko społeczne oraz przedmiot pracy socjalnej, w: I. Lepalczyk, T. Pilch (red.), Pedagogika społeczna. Wydawnictwo Akademickie „Żak”, Warszawa.

Dawid J.W. (2002). O duszy nauczycielstwa. Wydawnictwo KUL, Lublin.

Dzięcielska-Machnikowska S. (1993). Jak żyją bezrobotni w III Rzeczpospolitej. Uniwersytet Łódzki, Łódź.

Górski S. (1985). Metodyka resocjalizacji. Instytut Wydawniczy Związków Zawodowych, Warszawa. Graniewska D. (2001). Rodzina a bezrobocie - sytuacja w Polsce. „Problemy Rodziny”, 3.

Kawula S. (1998). Pedagogika społeczna w społeczeństwie ryzyka. Wydawnictwo Epistheme, Olsztyn.

Kawula S., Brągiel J., Janke A. (2009). Pedagogika rodziny. Wydawnictwo Adam Marszałek, Torun. Konopczyński M. (2006). Metody twórczej resocjalizacji. Wydawnictwo Naukowe PWN, Warszawa. Kowalska G. (2006). Bezrobocie polskich rodzin i jego konsekwencje. „Edukacja”, 2.

Kwak A., Mościskier A. (2002). Rzeczywistość praw dziecka w rodzinie. Wydawnictwo Akademickie „Żak”, Warszawa.

Lister R. (2007). Bieda. Wydawnictwo Sic!, Warszawa.

Łobocki M. (2003). ABC wychowania. Wydawnictwo UMCS, Lublin.

Misiewicz H. (1986). Rola rodziny w ksztaltowaniu postaw. Instytut Wydawniczy Związków Zawodowych, Warszawa.

Miś L., Nóżka M., Smagacz-Poziemska M. (2011). Nasze problemy. Bieda i bezrobocie we wspótczesnym spoteczeństwie polskim. Wydawnictwo „Universitas”, Kraków.

Nowak A., Wysocka E. (2001). Problemy i zagrożenia społeczne we wspótczesnym świecie. Wydawnictwo Naukowe „Śląsk”, Katowice.

Pieter J. (1972). Środowisko wychowawcze. Wydawnictwo Uniwersytetu Śląskiego, Katowice.

Pietrzyk A. (2001). Style wychowania dzieci w polskich rodzinach ubogich i zamożnych - podobieństwa i różnice. „Problemy Rodziny”, 2. 
Pilch T., Lepalczyk I. (red.) (2003). Pedagogika społeczna. Wydawnictwo Akademickie „Żak”, Warszawa.

Płusa S. (2015). Bieda wśród polskich dzieci, w: E. Sapia-Drewniak, M. Pogorzelska (red.), Społeczno-edukacyjne wymiary wykluczenia i dyskryminacji. W poszukiwaniu rozwiazań i dobrych praktyk. Wydawnictwo Uniwersytetu Opolskiego, Opole.

Przetacznik-Gierowska M., Włodarski Z. (1998). Psychologia wychowawcza. Wydawnictwo Naukowe PWN, Warszawa.

Radziewicz-Winnicki A., Roter A. (2004). Ryzyko transformacyjne nowego ładu społeczno-edukacyjnego. Wydawnictwo Śląskiej Wyższej Szkoły Zarządzania im. gen. Jerzego Ziętka, Katowice.

Ratajczak Z. (red.) (2001). Psychologia. Badania i aplikacje. T. 4: Bezrobocie. Między bezradnością a nadzieją. Wydawnictwo Uniwersytetu Śląskiego, Katowice.

Warzywoda-Kruszyńska W. (2010). Enklawy biedy-mechanizm powstawania i trwania. „Praca Socjalna", 7-8: 51-60.

Wódz K., Piątek K. (red.) (2004). Socjologia i polityka społeczna a aktualne problemy pracy socjalnej. Dylematy teorii i praktyki społecznej. Wydawnictwo Edukacyjne „Akapit”, Toruń. 